\section{Evaluation of Cool-season Vegetable Rotations in Organic Production}

\author{
George E. Boyhan ${ }^{1,5,10}$, Julia W. Gaskin ${ }^{2,6}$, Elizabeth L. Little ${ }^{3,7}$, \\ Esendugue G. Fonsah ${ }^{4,8}$, and Suzanne P. Stone ${ }^{1,9}$
}

ADDITIONAL INDEX WORDs. sustainable, summer cover crops, winter vegetables, soil amendments, National Organic Program, NOP

Summary. Certified organic production is challenging in the southeastern United States due to high weed, insect, and disease pressure. Maintaining and building soil organic carbon in midscale organic production systems can also be difficult due to the warm, moist conditions that promote decomposition. Focusing on cool-season cash crops paired with warm-season cover crops may help alleviate these production problems. This 3-year study (2011-13) evaluated two vegetable rotations of cool-season crops with cover crops for their productivity, disease management, and soil building potential in Watkinsville, GA. In the first rotation, cool-season cash crops included onion (Allium cepa), strawberry (Fragaria $\times$ ananassa), and potato (Solanum tuberosum). These crops were rotated with green bean (Phaseolus vulgaris), oats/austrian winter pea (Avena sativa/Pisum sativum ssp. arvense), southernpea (Vigna unguiculata), and sunn hemp (Crotalaria juncea). In the second rotation, cool-season cash crops included onion, broccoli (Brassica olevacea Italica group), lettuce (Lactuca sativa), and carrot (Daucus carota ssp. sativus). These were rotated with millet (Urochloa ramosa), sunn hemp, egyptian wheat/iron clay pea (Sorghum sp./Vigna unguiculata), and sorghum $\times$ sudangrass (Sorghum bicolor $\times$ S. bicolor var. sudanese)/iron clay pea. Onion yields in both rotations were at least $80 \%$ of average yields in Georgia. Lettuce yields were at least double the average yields in Georgia and were comparable to national averages in the 2 nd and 3 rd years of the study.

Strawberry yields in these rotations were lower than Georgia averages in all 3 years with a trend of lower yields over the course of the study. By contrast, potato, although lower than average yields in Georgia increased each year of the study. Broccoli yields in the first year were substantially lower than average Georgia yields, but were comparable to average yields in the 2 nd year. Carrot remained less than half of average Georgia yields. Green bean were half of average Georgia yields in the 2 nd year and were comparable to average yields in the 3rd year. As expected from what is observed in cool-season organic vegetable production in Georgia, disease pressure was low. Cover crops maintained soil organic carbon $(C)$ with a small increase in active $C$; however, there was a net loss of potentially mineralizable nitrogen (PMN). Active $\mathrm{C}$ averaged across both rotations at the beginning of the study at $464 \mathrm{mg} \cdot \mathrm{kg}^{-1}$ and averaged $572 \mathrm{mg} \cdot \mathrm{kg}^{-1}$ at the end of the study. On the basis of this study, using cover crops can maintain soil carbon without the addition of carbon sources such as compost. Finally, longer term work needs to be done to assess soil management strategies.

$\mathrm{T}$

here are two important trends with food in the United States. One is the increased demand

\footnotetext{
${ }^{1}$ Department of Horticulture, University of Georgia, 1111 Miller Plant Science Building, Athens, GA 30602

${ }^{2}$ Crop and Soil Science Department, University of Georgia, 4115B Miller Plant Science Building, Athens, GA 30602

${ }^{3}$ Department of Plant Pathology, University of Georgia, 2105 Miller Plant Science Building, Athens, GA 30602

${ }^{4}$ Department of Agricultural and Applied Economics, 2360 Rainwater Road, Tifton, GA 31793

${ }^{5}$ Professor and Extension Vegetable Specialist

${ }^{6}$ Sustainable Agriculture Coordinator

${ }^{7}$ Assistant Professor

${ }^{8}$ Extension Economist

${ }^{9} \mathrm{PhD}$ Graduate Student

${ }^{10}$ Corresponding author. E-mail: gboyhan@uga.edu.

doi: 10.21273/HORTTECH03443-16
}

for certified organic produce and the other is the interest in local food. The intersection of these trends has increased the demand for organic produce grown in the southeastern United States. Institutions such as Emory University have made a commitment that $75 \%$ of their food will be sustainably grown or locally sourced by 2015 (Emory University, 2008). Large grocery chains are looking for suppliers of local organic produce. This increased demand has sparked an interest among conventional vegetable growers in certified organic production techniques and has put increasing demand on existing organic growers. Discussions with organic growers, particularly in northeast Georgia indicate demand exceeds supply. Growers themselves have identified the need for better production information and the need for research-based information on crop rotations adapted to regional growing conditions.

Organic farms in the Piedmont area of northern Georgia tend to be smaller in size and have developed niche markets around larger population centers; however, there are opportunities for midscale organic production to meet wholesale demand. Piedmont soils typically have little organic matter and low intrinsic fertility (Perkins, 1987). Organic management systems use cover crops and compost to increase soil organic matter and build fertility, but a hot, humid climate such as in the southeastern United States can rapidly oxidize organic matter, particularly when cultivation is used for weed control.

Crop rotation is one of the many bed rocks on which organic agriculture is built. Crop rotation is important in managing soil fertility and soilborne pests, which includes both diseases and weeds. Many different rotations have been proposed to deal with these problems. Sarrantonio (1992) recommended including various soil-improving crops in temporal niches that existed in current crop production systems. For example, including a summer cover crop between spring broccoli and fall lettuce or cover crops in the spring and fall with summer tomato (Solanum lycopersicum) production.

\begin{tabular}{llll}
\hline $\begin{array}{l}\text { Units } \\
\text { To convert U.S. to SI, } \\
\text { multiply by }\end{array}$ & U.S. unit & SI unit & $\begin{array}{l}\text { To convert SI to U.S., } \\
\text { multiply by }\end{array}$ \\
\hline 0.3048 & $\mathrm{ft}$ & $\mathrm{m}$ & 3.2808 \\
3.7854 & $\mathrm{gal}$ & $\mathrm{L}$ & 0.2642 \\
2.54 & inch(es) & $\mathrm{cm}$ & 0.3937 \\
1.1209 & lb/acre & $\mathrm{kg} \cdot \mathrm{ha}^{-1}$ & 0.8922 \\
0.0254 & $\mathrm{mil}$ & $\mathrm{mm}$ & 39.3701 \\
1 & $\mathrm{ppm}$ & $\mathrm{mg} \cdot \mathrm{kg}^{-1}$ & 1 \\
6.8948 & $\mathrm{psi}$ & $\mathrm{kPa}$ & 0.1450 \\
$\left({ }^{\circ} \mathrm{F}-32\right) \div 1.8$ & ${ }^{\circ} \mathrm{F}$ & ${ }^{\circ} \mathrm{C}$ & $\left({ }^{\circ} \mathrm{C} \times 1.8\right)+32$
\end{tabular}


There is relatively little information on choosing a cover crop for these functions in vegetable production, particularly in the southeastern United States. In onion production on muck soils in Michigan using brassica (Brassica sp.) cover crops or sorghum $\times$ sudangrass (sudex) resulted in similar weed suppression and soil fertility regardless of the cover crop used. Cover crops compared in this study were brown mustard (Brassica juncea), 'Daikon' oilseed radish (Raphanus sativus), oriental mustard (B. juncea), 'Tilney' yellow mustard (Sinapis alba), and sudex (Wang et al., 2008).

Studies have shown the use of crop rotations and cover crops diminish disease severity (percent host tissue infected) and incidence [i.e., number of plants infected (Koike et al., 2000)]. Alternating nonhost crops after a host crop can lessen the season-to-season survival of host-specific pathogens. The increase in soil organic matter associated with these practices not only improves plant health, but the increase in soil microbial diversity may reduce the ability of some soilborne pathogens to survive and infect. Soilborne pathogens with a wide host range and long-lived propagules, such as Sclerotium rolfsii, Sclerotinia species, and root-knot nematodes (RKNs) (Melodogyne sp.), are particularly troublesome in the warm soils of the southeastern United States, and must be managed with rotations of nonhost cover crops (Clark, 2007).

Crop rotation with cover crops has been found to reduce nematode populations. Sunn hemp and southernpea used as a summer rotation in Florida tomato plots were found to suppress plant pathogenic nematodes while enhancing beneficial nematodes (Wang et al., 2002). In a controlled experiment, preplant incorporation of wheat (Triticum aestivum) residues significantly reduced RKN galling on tomato roots and completely inhibited germination of $S$. rolfsii sclerotia at soil temperatures of $23{ }^{\circ} \mathrm{C}$ (Stapleton et al., 2010).

A shift from warm-season cash crops when pest pressure are highest to cool-season cash crops when these pressures are lower may help midscale farmers develop more profitable operations to meet demand for certified organic produce. Organic farmers focusing on cool-season cash crops would primarily use warm-season cover crops to improve soil quality and manage pests; however, there is relatively little research-based information available on optimal production systems for the southeastern United States with cool-season vegetables. Constructing midscale rotations that meet multiple objectives of profitability, building soil, and suppressing pests can be a challenge and growers must be shown the economic benefit of these rotations. Current organic vegetable production studies tend to focus only on one crop. The purpose of this project was to take a systems approach to evaluate two different crop rotations that focused on cool-season cash crops and included cover crops to meet these multiple objectives and produce high value certified organic vegetables.

\section{Materials and methods}

The rotation research was conducted on certified organic land at the University of Georgia Durham Horticulture Farm in Watkinsville, GA (lat. $33^{\circ} 55^{\prime} \mathrm{N}$, long. $83^{\circ} 25^{\prime} \mathrm{W}$ ). Soils at the study site were a Cecil sandy loam (Fine, kaolinitic, and thermic Typic Kanhapludults) that had been managed organically since 2007 so initial soil organic carbon of $1.51 \%$ was greater than the $1.02 \% \mathrm{C}$ typically reported for this series when cultivated (Perkins, 1987). Available phosphorus $[\mathrm{P}(168 \mathrm{ppm})]$ was in the very high range and available potassium $[\mathrm{K}(138 \mathrm{ppm})]$ was in the high range. The initial $\mathrm{pH}$ was 6.8 .

The experiment consisted of two 3 -year rotations. Each entry point for a rotation was grown every year [six treatments consisting of three entry points for each of two rotations (Table 1)]. The experiment was a randomized complete block design with

Table 1. Two rotations with six different starting crops indicated as entry points indicating the crop sequence at Watkinsville, GA, in 2011-13.

\begin{tabular}{llllllll}
\hline Entry point & \multicolumn{7}{c}{${\text { Rotation } \mathbf{A}^{\mathrm{z}}}$} \\
\hline 1 & STR & GRB & OAP & POT & SUN & ONO & SOP \\
2 & OAP & POT & SUN & ONO & SOP & STR & GRB \\
3 & ONO & SOP & STR & GRB & OAP & POT & SUN \\
& & & \multicolumn{7}{c}{ Rotation B } & & & \\
1 & BRO & LET & MIL & CAR & SUN & ONO & MIL \\
2 & CAR & SUN & ONO & MIL & BRO & LET & SUX \\
3 & ONO & EGY & BRO & LET & MIL & CAR & SUN \\
\hline
\end{tabular}

$\mathrm{BRO}=$ broccoli $; \mathrm{CAR}=$ carrot $; \mathrm{EGY}=$ egyptian wheat $/$ iron clay pea $; \mathrm{GRB}=$ green bean; $\mathrm{LET}=$ lettuce, $\mathrm{MIL}=$ millet OAP $=$ oats $/$ austrian winter pea ONO = onion; $\mathrm{POT}=$ potato $; \mathrm{SOP}=$ southernpea $; \mathrm{STR}=$ strawberry; SUN = sunn hemp; SUX = sudex/iron clay pea.

${ }^{z}$ Each rotation started with a different crop; however, the sequence was the same within each rotation. three replications. Each experimental unit consisted of a plot $50 \mathrm{ft}$ long of the prepared bed with an approximate bed top of $4 \mathrm{ft}$ wide.

There are no standard rotations used by farmers in the region; consequently, we focused on cool-season crops widely grown in the area or ones that have consistent demand. The first rotation consisted of three coolseason cash crops: onion, strawberry, and potato. There was one winter cover crop, oats/austrian winter pea to avoid leaving fallow land. Also included in the first rotation was a warmseason vegetable, green bean that could potentially generate cash flow during summer months. Finally, there were two summer cover crops of southernpea consisted of four cool-season vegetables: onion, broccoli, lettuce, and carrot. There were four summer cover crops: millet, sunn hemp, egyptian wheat/iron clay pea, and sudex.

The experiment began in Fall 2010 with the turning under and incorporating of a previous cover crop of sunn hemp. Beds were prepared with $6 \mathrm{ft}$ center to center between rows. Onion and strawberry were planted on plastic covered beds (prepared Sept. 2010), which was 1-mil-thick black on white (Sigma Plastics Group, Lyndhurst, NJ) with a single drip irrigation line $\left(8\right.$-inch emitter spacing, $0.2 \mathrm{gal} \cdot \mathrm{h}^{-1}$ at $10 \mathrm{psi}$ ) placed under the plastic. Broccoli and lettuce were planted on ing specifications are given in Table 2.

Strawberry was planted with two rows on the bed with between plant spacing of 18 inches. Green bean was planted with two rows per plot with between-row spacing of 18 inches and in-row spacing of 4 inches. Potato and sunn hemp. The second rotation plastic covered beds the first year and 
Table 2. Crops, varieties, entry points within a rotation, planting, and harvest dates for two cool-season cash crop rotations at Watkinsville, GA, in 2011-13.

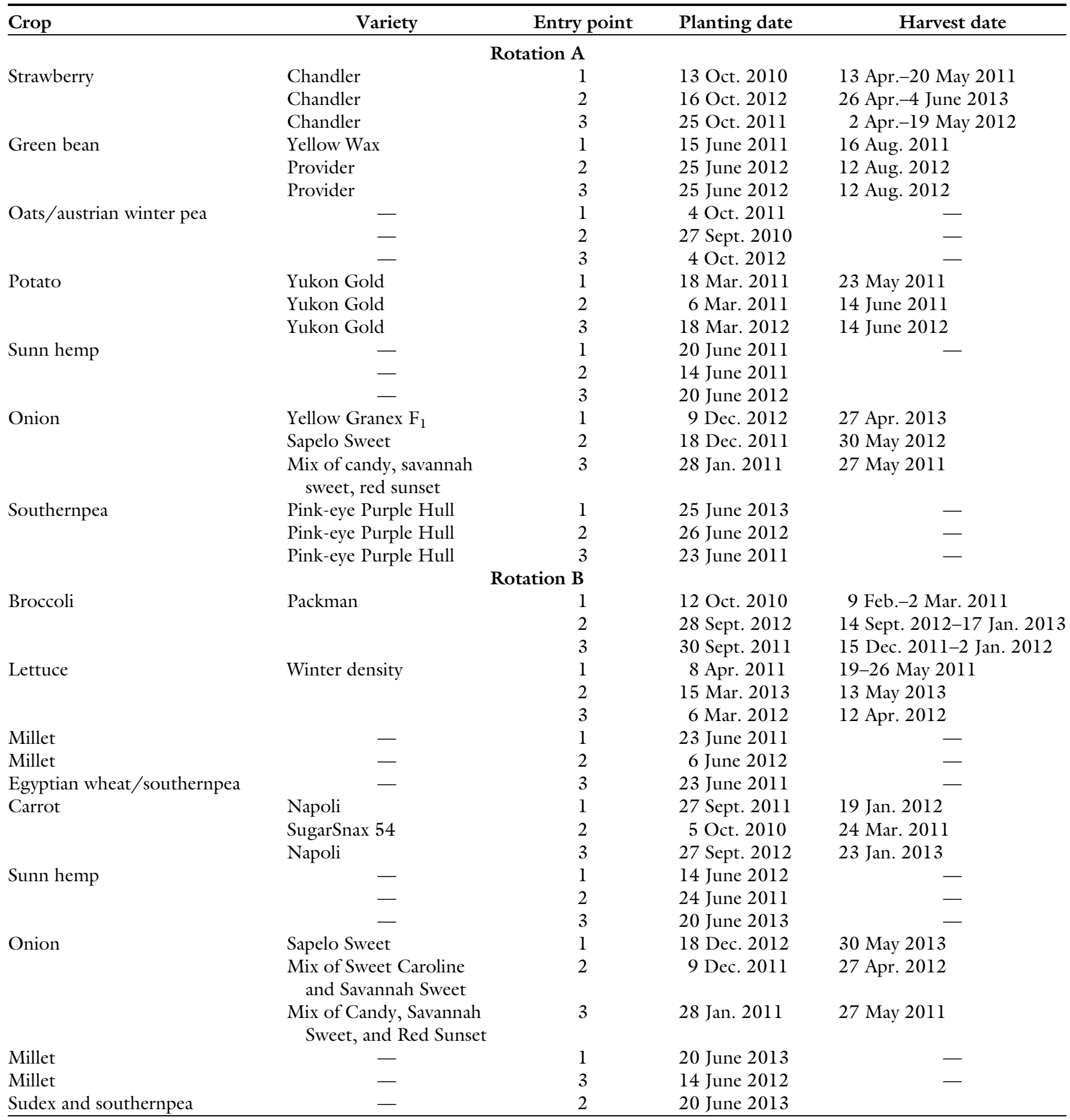

seed pieces were planted with two rows per bed with a 12 inches between-row and in-row spacing. Onion was planted with four rows per plot with betweenrow spacing of 12 inches and in-row spacing of 6 inches. Southernpea was planted with two rows per plot with between-row spacing of 12 inches and in-row spacing of 4 inches. Broccoli was planted with two rows with
18 inches between-row spacing and 12 inches in-row spacing. Lettuce was planted with four rows with betweenrow spacing of 6 inches and in-row spacing of 5 inches. Carrot was planted with four rows per plot with betweenrow spacing of 12 inches and in-row spacing of 2 inches. Oats/austrian winter pea was sown at a rate of 50 and $40 \mathrm{lb} /$ acre, respectively. Egyptian wheat/iron clay pea was sown at rates of 40 and $50 \mathrm{lb} /$ acre, respectively. Sunn hemp was sown at $80 \mathrm{lb} /$ acre and millet was sown at $40 \mathrm{lb} /$ acre.

All the crops were grown according to U.S. Department of Agriculture (USDA) National Organic Program rules for organic production and University of Georgia Cooperative Extension Service recommendation for 
fertility with adjustments for cover crop nitrogen $(\mathrm{N})$ credits (Table 3 ). Fertilizer sources included legume cover crops in the rotations, and commercial organic, pelleted animal byproduct fertilizer (Nature Safe 10N-0.9P-6.6K and $13 \mathrm{~N}-0 \mathrm{P}-0 \mathrm{~K}$; Darling Ingredients, Irving, TX). The use of the Nature Safe complete fertilizer meant that $\mathrm{P}$ and $\mathrm{K}$ were over or under applied for some crops. Potassium levels were supplemented with potassium sulfate as needed. An N credit was given for cover crops based on values in the literature (Sarrantonio, 2007; Schomberg et al., 2007) (Table 3). All the recommended fertilizer was applied before final bed preparation and application of the plastic mulch.

Weeds were controlled as needed with hand weeding. No effort was made to control diseases because disease evaluation was an important part of the experiment. Insect control on broccoli consisted of a single application of Bacillus thuringiensis (Dipel; Valent Biosciences, Libertyville, IL) applied on 13 Oct. 2010 according to label directions.

Data on harvest date and yield were collected for each vegetable crop. All vegetables were harvested when judged mature for fresh market sales. The crops, varieties, rotation entry points, planting, and harvest dates are listed in Table 2

Changes in soil quality were measured using total $\mathrm{C}$ and $\mathrm{N}, \mathrm{PMN}$, active $\mathrm{C}, \mathrm{pH}$, and Mehlich extractable $\mathrm{P}, \mathrm{K}$, calcium (Ca), magnesium ( $\mathrm{Mg})$, and zinc $(\mathrm{Zn})$. Soil samples for the analyses were collected in the fall of each year from 0 to $15 \mathrm{~cm}$. Total $\mathrm{C}$ and $\mathrm{N}$ were measured by combustion (CNS-2000; LECO, St. Joseph, MI). PMN was measured as ammonium nitrogen $\left(\mathrm{NH}_{4}-\mathrm{N}\right)$ using a hot minus cold potassium chloride extraction (Gianello and Bremner, 1986). Active C was measured using a weak potassium permanganate oxidation (Weil et al., 2003). This $C$ fraction has been shown to more quickly respond to management changes than total $\mathrm{C}$ (Culman et al., 2012). Soil pH was determined on a 2.5:1 soil:water paste (Thomas, 1996). The Mehlich I extraction is a weak double acid extraction used for fertility recommendations in Georgia (Kissel and Sonon, 2008). Results from the PMN, Mehlich I analyses, and book values for available $\mathrm{N}$ from cover crops were used to guide the fertility recommendations. During year 3, we began testing a new cover crop $\mathrm{N}$ production tool-Cover Crop Nitrogen Availability Calculator (University of Georgia, 2011). The calculator uses soil and cover crop characteristics along with local weather station data to predict the amount of $\mathrm{N}$ released over the growing season. The prediction from the tool was compared with estimates of cover crop available $\mathrm{N}$ from the literature and used to help interpret yield data.

High value cool-season crops were evaluated for incidence and severity of the major pathogens that constrain organic production to assess the beneficial effects of cover crops on disease suppression. The following major diseases were assessed: S. rolfsii and other root pathogens on carrot (Smith et al., 1988), Botrytis cinerea and Colletotrichum acutatum on strawberry (Chandler, 2006), Botrytis species and Burkholderia species on onion (Adam, 2006), and Pectobacterium carotovorum and other soilborne diseases on potato (Stevenson et al., 2001). Any additional diseases causing significant damage were assessed and identified, with particular attention paid to the incidence of important soilborne pathogens that have the ability to infect multiple crop families, such as Rbizoctonia, Sclerotium, Sclerotinia, and Pectobacterium species. High-value cool-season crops were evaluated during the growing season for

Table 3. First year soil test-based fertilizer recommendations and actual nutrient application rates for elemental nitrogen, phosphorus, and potassium for vegetables and cover crops with nitrogen credit and cover crop source at Watkinsville, GA, in 2011-13.

\begin{tabular}{|c|c|c|c|c|c|c|c|}
\hline \multirow[b]{3}{*}{ Crop $^{z}$} & \multicolumn{2}{|c|}{ Nitrogen } & \multicolumn{2}{|c|}{ Phosphorus } & \multicolumn{2}{|c|}{ Potassium } & \multirow{3}{*}{$\begin{array}{l}\text { Nitrogen credit and } \\
\text { cover crop source }\end{array}$} \\
\hline & Applied & Recommended & Applied & Recommended & Applied & Recommended & \\
\hline & \multicolumn{6}{|c|}{$(\text { lb/acre })^{y}$} & \\
\hline Strawberry & 100 & 110 & 8.6 & 0 & 67 & 58 & 9.8, Southernpea \\
\hline Bush bean & 90 & 80 & 7.8 & 0 & 58 & 58 & \\
\hline $\begin{array}{l}\text { Oats/austrian } \\
\text { winter pea }\end{array}$ & 0 & & 0 & & 0 & & \\
\hline Sunn hemp & 0 & & 0 & & 0 & & \\
\hline Onion & 30 & 120 & 2.8 & 20 & 76 & 75 & 90, Sunn hemp \\
\hline Southernpea & 40 & 40 & 3.5 & 0 & 26 & 33 & \\
\hline & & & & Rotation B & & & \\
\hline Sunn hemp & 0 & & 0 & & 0 & & \\
\hline Onion & 30 & 120 & 2.8 & 20 & 68 & 75 & 80, Sunn hemp \\
\hline Millet & 0 & 0 & 0 & 0 & 0 & 0 & \\
\hline
\end{tabular}

${ }^{\mathrm{z}}$ Rotation A: total nitrogen credit $=146 \mathrm{~kg} \cdot \mathrm{ha}^{-1}(130.3 \mathrm{lb} / \mathrm{acre})$, Rotation B: total nitrogen credit $=15 \mathrm{l} \mathrm{kg} \cdot \mathrm{ha}{ }^{-1}(134.7 \mathrm{lb} / \mathrm{acre})$.

${ }^{y} \mathrm{l} \mathrm{lb} / \mathrm{acre}=1.1209 \mathrm{~kg} \cdot \mathrm{ha}^{-1}$. 
disease incidence (number of plants with symptoms) and severity (percentage of plant tissue damaged) and samples were collected as needed for pathogen identification. At harvest, the entire crop was evaluated for incidence and severity of disease. Confirmation of pathogen identity was based on visual, cultural, serological, and or DNA-based techniques as appropriate for the different pathogen groups.

Strawberry fruit was evaluated for fruit rot caused by $C$. acutatum and $B$. cinerea by determining the percentage of fruit from each treatment exhibiting disease symptoms. Strawberry roots of individual plants within each treatment were rated for incidence of root rot by examining a random sampling of root segments for symptoms (Copes and Stevenson, 2008). Onion foliage was evaluated for incidence (number of plants infected) and severity (visual assessment of percent leaf area infected) from botrytis leaf blight (Botrytis squamosa). A preliminary diagnosis of the fungal pathogens associated with leaf and fruit diseases was made by visual examination for characteristic symptoms and pathogen structures. Pathogen identity was confirmed from a subset of infected fruit and leaves after isolation onto media using standard methods (Dhingra and Sinclair, 1985). Harvested potato tubers and carrot roots were examined for the incidence and severity of disease lesions. The identity of soilborne fungal pathogens was confirmed using standard methods. Root crops were assessed for the incidence of bacterial soft rots caused by $P$. carotovorum and Burkholderia gladioli pv. alliicola and the identity was confirmed using standard methods for plant pathogenic bacteria (Schaad et al., 2001).

Pathogenic nematode populations were enumerated in soil samples at three time points within a year to evaluate the effects of the rotation on nematode numbers. Soil samples were collected just before the harvest of the winter vegetable crops (February), spring vegetable crops (end of May), and summer cover crops (September). Soil samples were collected based on the recommendations of the University of Georgia Plant Nematology Laboratory (2004). One bulked soil sample from each experimental unit consisting of 20-subplot soil cores randomly sampled throughout the plot in the root zone of the crop. Samples were submitted to the University of Georgia Plant Nematode Laboratory for evaluation of all common plant parasitic nematode genera.

Yield data were collected for all winter vegetables in the study. The change in soil quality from the initial soil sampling in Fall 2010 to final soil sampling Fall 2013 due to rotation was evaluated using a $t$ test $[P \leq 0.05$ (SAS Enterprise Guide 4.3; SAS Institute, Carey, NC)]. For each rotation, we also tested whether the change in soil quality parameters was significantly different from zero using a $t$ test $(P \leq 0.05)$. The $t$ test $(P \leq 0.05)$ was also used to compare harvested yield to average yield for the respective crops (Stata 14.1; StataCorp, College Station, TX).

\section{Results and discussion}

SoILs. There were no significant changes in the overall characteristics of soil in the study due to the different rotations. Soil $\mathrm{pH}$ ranged from 6.7 to 6.8 over the study. There were no differences in soil test $\mathrm{P}$, which ranged from 138 to $181 \mathrm{ppm}$ and remained in the very-high range (> $75 \mathrm{ppm})$ throughout the study. Phosphorus was added at a rate of $2.8-15.3 \mathrm{lb} /$ acre each year.

There were no differences in soil test $\mathrm{K}$ between the two rotations. Overall, soil test $\mathrm{K}$ decreased during the study from a high to a medium $(75 \mathrm{ppm})$ in both rotations. Potassium was over applied on the strawberry, broccoli, and lettuce, and under applied on potato based on soil test recommendations (Table 3 ). This was because of the fertilizer formulations used, $10 \mathrm{~N}-0.9 \mathrm{P}-6.6 \mathrm{~K}$. Other research on organic systems has indicated that $\mathrm{K}$ levels may be difficult to maintain (Goulding et al., 2008).

There was little change in total soil $\mathrm{C}$ over the 3-year period (Rotation $\mathrm{A}=0.04 \%$ and Rotation $\mathrm{B}=-0.08 \%$ ) and no difference between rotations $(P=0.246)$. This is not surprising because total $\mathrm{C}$ in the soil is known to change very slowly in response to management (Culman et al., 2012). There was an increase of 100-120 ppm in active $\mathrm{C}$ over the duration of the study; however, there was no difference between the two rotations. Active $\mathrm{C}$ is known to respond quickly to management changes (Culman et al., 2012). The increase in active C indicates that the crop rotation with summer cover crops may be sufficient to maintain soil organic C. This is important for midscale farmers who may be interested in wholesale markets, because purchasing compost to maintain soil quality is a considerable expense and may make their harvest uneconomic.

PMN concentrations initially averaged $8.2 \mathrm{ppm}$ in the Rotation A plots and $8.5 \mathrm{ppm}$ in the Rotation B plots. Sharifi et al. (2007) reported averages for 153 soils from the United States and Canada at $7.4 \mathrm{ppm}$. In both rotations $A$ and $B$, there was a significant net loss of PMN over time with a net average loss of $7.2 \mathrm{ppm}$ in Rotation $\mathrm{A}$ and $7.5 \mathrm{ppm}$ in Rotation $\mathrm{B}$. There was no difference in the change in PMN due to rotation. The decrease in PMN over time was surprising because we would expect it to change in a similar fashion to the active $C$ fraction. Both PMN and active $\mathrm{C}$ are designed to measure easily the decomposable fraction of soil organic matter, which is largely related to soil microbial biomass (Idowu et al., 2009). The largest decrease occurred between Fall 2012 and Fall 2013 (Fig. 1). Summer 2013 was extremely wet with precipitation 26.4 inches from 1 June to 31 Aug. compared with the average of 12.6 inches for this period in 2012 (University of Georgia, 1991). This may have accelerated $\mathrm{N}$ leaching from the system.

Disease AND Nematodes. Generally, there was low disease pressure in the study across all crops grown. There was a minor infection of botrytis leaf blight on onion foliage every year before harvest that did not appear to affect yield. There are several species of botrytis that affect onion with $B$. squamosa causing botrytis leaf blight in onion. Late in the season, $\approx 1$ month before harvest, purple blotch (Alternaria porri) blighted the onion foliage in both 2012 and 2013. This pathogen occurs during the warm wet weather of late spring. No significant differences were seen between rotations.

In 2012, lettuce drop caused by Sclerotinia sclerotiorum resulted in a disease incidence of $5 \%$ to $7 \%$. This disease has a wide host range and form sclerotia in the soil that can persist for relatively long periods of time. In 2012, the mild wet spring weather favored development of the 


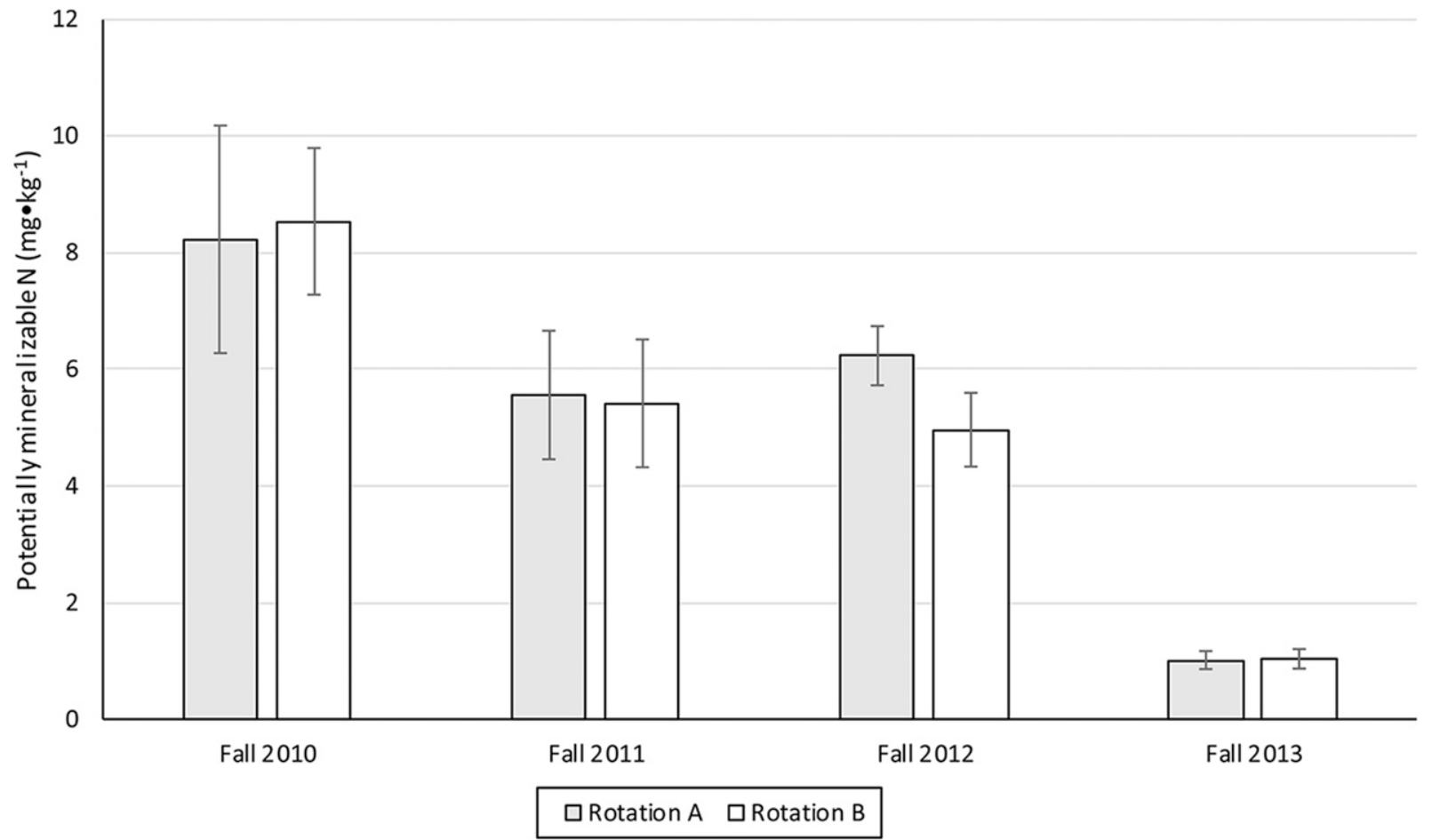

Fig. 1. Potentially mineralizable nitrogen $(\mathrm{N})$ in the soil $[0-15 \mathrm{~cm}(5.9$ inches $)]$ in the two crop rotations compared during the organic cool-season crop rotation study at the Durham Horticulture Farm in Watkinsville, GA; $1 \mathrm{mg} \cdot \mathrm{kg}^{-1}=1 \mathrm{ppm}$.

disease on lettuce. Crop rotation to nonhosts and maintaining soil moisture during periods of high soil temperature can reduce the sclerotia found in the soil thus reducing the potential for future infections. This pathogen was also found in one replication of the bean crop later in the 2012 season although losses were not significant.

In 2013, but not in the other 2 years, about one-third of the bean plants in one plot were killed by southern blight ( $S$. rolfsii). In 2013, there was abundant rainfall during the summer months, making for ideal disease conditions (Fig. 2). This can be a difficult pathogen to control because of long-lived sclerotia in the soil and the wide host range. Crop rotation to nonpreferred hosts and cover crops, combined with adequate soil organic matter and moisture management to keep the crowns of plants dry, are the best methods for organic management. Interestingly, the affected bean plot was located on the grassy edge of the rotation study while the other plots, which were surrounded by other crops, were unaffected. This may be an indication of microclimate effects that can have an impact on disease suppression or the importance of barrier crops in preventing disease invasion.
The only plant parasitic nematode found at damaging levels during the study was $\mathrm{RKN}$, with a damage threshold of one for vegetable crops. RKN populations increased from undetectable levels over the course of the study, although they did not consistently reach detectable levels in any one plot. Detection of high $(n>3)$ populations occurred in late Summer 2012 after strawberry/bush bean crops $(\mathrm{n}=14)$, in late Winter 2013 after oats/austrian winter pea $(\mathrm{n}=7)$, and in late Summer 2013 after the lettuce/ sudex crops $(n=10)$. All of the plots with high RKN numbers were within one replication block. Lower numbers of $\mathrm{RKN}(\mathrm{n} \leq 3)$ were found in plots across all replications with one plot each in late Summer 2011 and 2012, and late Spring 2012. By late Summer 2012 , there were three plots with low detectable numbers and this increased to five plots in late Summer 2013. Sunn hemp appeared to suppress these populations although a longer study would be needed to see if the increase in nematodes was a long-term trend. RKN can be a major problem in organic vegetable production in the southeastern United States. Adequate incorporation of high-quality soil organic matter combined with proper selection of rotations and cover crops can suppress RKN populations and other soilborne diseases, and this should be a consideration when scaling up organic production (Wang et al., 2007). Further investigations are needed to develop effective methods for suppressing RKN in organic vegetable production under southeastern U.S. conditions.

The strawberry leaves were infected with leaf spot (Mycosphaerella fragariae) during the fall and winter, but the disease was confined to older leaves and was not severe enough to cause any significant losses. There was an occasional low incidence of fruit rot from gray mold (B. cinerea) after periods of rain, but no evidence of root rot. Strawberry plants were remarkably free of disease.

Potato had some wireworm (Conoderusfalli) damage the first year in one plot close to the field edge, but no significant disease problems. Finally, there were no significant diseases on carrot.

YIELDS. In both rotations, $A$ and $B$, onion did as well or better than the average Georgia yields for onion (Tables 4-6). Conventionally produced onion in Georgia are grown on bareground; however, in this experiment onion were grown with plastic mulch primarily for weed control. Onion is 


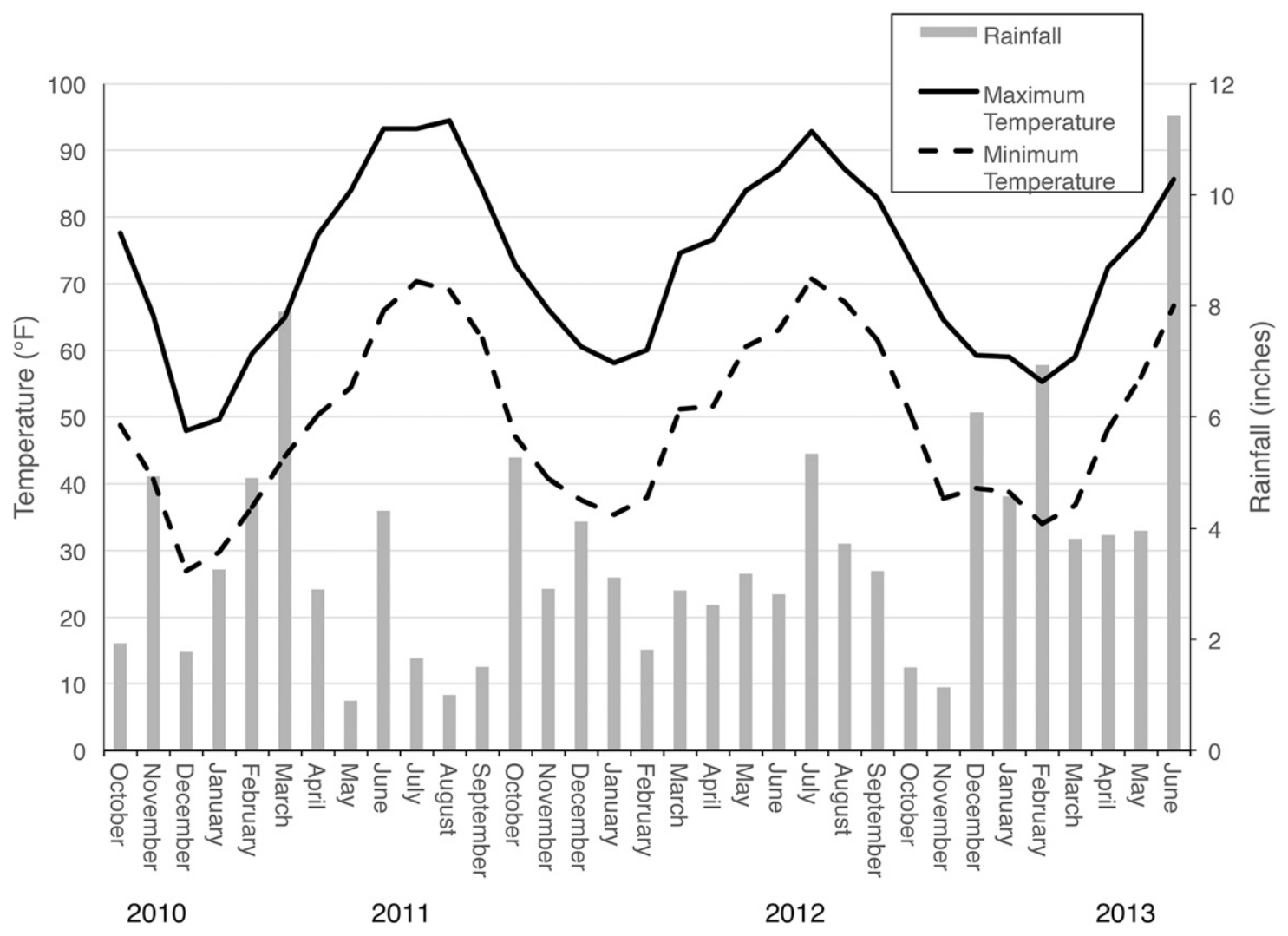

Fig. 2. Average monthly minimum and maximum temperatures, as well as, accumulated monthly rainfall during the course of the study $(2010-13) ;\left({ }^{\circ} \mathrm{F}-32\right) \times 1.8={ }^{\circ} \mathrm{C}, 1$ inch $=2.54 \mathrm{~cm}$.

Table 4. Cool-season rotations A (entry points $1-3$ ) and B (entry points 1-3) with total yield, average yield, probability of total yield greater than average yield, and planting and harvest dates at Watkinsville, GA, in 2010-11 (year 1).

\begin{tabular}{|c|c|c|c|c|}
\hline \multirow[b]{2}{*}{ Entry } & \multirow[b]{2}{*}{ Entry point } & Total yield & Avg yield ${ }^{z}$ & \multirow[b]{2}{*}{ Probability } \\
\hline & & \multicolumn{2}{|c|}{ (lb/acre) } & \\
\hline \multicolumn{5}{|c|}{ Rotation A } \\
\hline Strawberry & 1 & 15,124 & 21,003 & 1.000 \\
\hline Potato & 2 & 8,757 & 15,603 & 0.973 \\
\hline Onion & 3 & 19,284 & 23,969 & 0.790 \\
\hline \multicolumn{5}{|c|}{ Rotation B } \\
\hline Broccoli & 1 & 2,766 & 10,122 & 0.997 \\
\hline Lettuce & 1 & 11,497 & 5,801 & 0.021 \\
\hline Carrot & 2 & 9,911 & 30,869 & 0.998 \\
\hline Onion & 3 & 24,698 & 23,969 & 0.432 \\
\hline
\end{tabular}

${ }^{2}$ Values are from 2009 Georgia farm gate report (Boatright and McKissick, 2010) and the U.S. Department of Agriculture strawberry yields for Florida (USDA, 2012); $1 \mathrm{lb} / \mathrm{acre}=1.1209 \mathrm{~kg} \cdot \mathrm{ha}^{-1}$.

yProbability that the measured total yield is greater than the average yield.

Planting date refers to either date direct seeded (potato, carrot) or transplanting date (strawberry, onion, broccoli, and lettuce).

sensitive to weed pressure, and herbicides allowed in certified organic production are not selective and there would be a high probability of damaging the onion. Hand weeding on a midscale farm would be prohibitively expensive. Plastic mulch offers several advantages for production, along with weed control, conservation of nutrients (less prone to leaching), maintaining soil moisture, and increasing soil temperature. Of course, plastic mulch is a nonbiodegradable product that is manufactured from nonrenewable petroleum.

The onion had a significant reliance on the previous cover crop residue for $\mathrm{N}$ (Table 3). The sunn hemp cover crop and soil appeared to supply $\approx 90 \mathrm{lb} /$ acre $\mathrm{N}$ for the following onion crop. Our modeling of $\mathrm{N}$ release in the 3 rd year indicated the cover crop; soil organic matter and inorganic $\mathrm{N}$ were significant sources of $\mathrm{N}$ (average cover crop $\mathrm{N}=59 \mathrm{lb} /$ acre, average soil organic matter $\mathrm{N}=35 \mathrm{lb} / \mathrm{acre}$, inorganic $\mathrm{N}=15 \mathrm{lb} /$ acre). Finally, the relatively high onion yields may be partially due to the fact they were grown outside the traditional onion belt of southeast Georgia where disease pressure would presumably be higher. Although onion did well in comparison with average farm gate yields, the onion sizes were generally smaller than what is traditionally produced in conventional production. Most of the onions were in the medium size class $(2-$ 3 inches), while in conventional onion production most are in the jumbo size ( $\geq 3$ inches). Conventional onion production will have $\approx 80 \%$ of the onion in the jumbo size class. It should be noted that there is increasing consumer preference for the medium size onion ( $\mathrm{R}$. Torrance, personal communication), apparently because this is the right size for cooking without leftover onion pieces.

Strawberry on the other hand did not produce well with yields going 
Table 5. Cool-season rotations A (entry points $1-3$ ) and B (entry points 1-3) with total yield, average yield, probability of total yield greater than average yield, and planting and harvest dates at Watkinsville, GA, in 2011-12 (year 2).

\begin{tabular}{|c|c|c|c|c|}
\hline \multirow[b]{2}{*}{ Crop } & \multirow[b]{2}{*}{ Entry point } & Total yield & Avg yield ${ }^{\mathrm{z}}$ & \multirow[b]{2}{*}{ Probability } \\
\hline & & \multicolumn{2}{|c|}{ (lb/acre) } & \\
\hline \multicolumn{5}{|c|}{ Rotation A } \\
\hline Potato & 1 & 10,983 & 15,603 & 0.971 \\
\hline Onion & 2 & 35,618 & 23,969 & 0.002 \\
\hline Southernpea & 2 & 3,607 & 2,876 & 0.021 \\
\hline Strawberry & 3 & 8,646 & 21,003 & 0.999 \\
\hline Green bean & 3 & 3,033 & 5,400 & 0.832 \\
\hline \multicolumn{5}{|c|}{ Rotation B } \\
\hline Carrot & 1 & 11,630 & 30,869 & 0.997 \\
\hline Onion & 2 & 35,384 & 23,969 & 0.009 \\
\hline Broccoli & 3 & 6,208 & 10,122 & 0.990 \\
\hline Lettuce & 3 & 21,863 & 5,801 & 0.038 \\
\hline
\end{tabular}

${ }^{2}$ Values are from 2009 Georgia farm gate report (Boatright and McKissick, 2010) and the U.S. Department of Agriculture strawberry yields for Florida (USDA, 2012); $1 \mathrm{lb} / \mathrm{acre}=1.1209 \mathrm{~kg} \cdot \mathrm{ha}^{-1}$.

"Probability that the measured total yield is greater than the average yield.

Planting date refers to either date direct seeded (potato, southernpea, green bean, and carrot) or transplanting date (onion, strawberry, broccoli, and lettuce).

Table 6. Cool-season rotations A (entry points 1-3) and B (entry points 1-3) with total yield, average yield, probability of total yield greater than average yield, and planting and harvest dates at Watkinsville, GA in 2012-13 (year 3).

\begin{tabular}{lccrc}
\hline & & Total yield & Avg yield $^{\mathrm{z}}$ & \\
\cline { 3 - 3 } Crop & Entry point & Rotation A & Probability $^{\mathrm{y}}$ \\
\cline { 3 - 4 } Onion & 1 & 25,926 & 23,969 & \\
Strawberry & 2 & 4,300 & 21,003 & 0.154 \\
Green bean & 2 & 5,074 & 5,400 & 1.000 \\
Potato & 3 & 13,307 & 15,603 & 0.623 \\
& & Rotation B & & 0.816 \\
Onion & 1 & 26,409 & 23,969 & 0.327 \\
Broccoli & 2 & 10,232 & 10,122 & 0.449 \\
Lettuce & 2 & 18,669 & 5,801 & 0.005 \\
Carrot & 3 & 13,481 & 30,869 & 0.999 \\
\hline
\end{tabular}

${ }^{2}$ Values are from 2009 Georgia farm gate report (Boatright and McKissick, 2010) and the U.S. Department of Agriculture strawberry yields for Florida (USDA, 2012); $1 \mathrm{lb} / \mathrm{acre}=1.1209 \mathrm{~kg} \cdot \mathrm{ha}^{-1}$.

yprobability that the measured total yield is greater than the average yield.

Planting date refers to either date direct seeded (potato, southernpea, green bean, and carrot) or transplanting date (onion, strawberry, broccoli, and lettuce).

down over the course of the 3 years. In all years, yields were significantly lower than the USDA estimates (Tables 4-6). The relatively high yields the first year may have been due to previous soil management where there was yearly compost application. There was a small $\mathrm{N}$ credit given from the preceding southernpea crop with a concommitant small reduction in $\mathrm{N}$ applied. The previous southernpea crop may not have contributed the $\mathrm{N}$ expected resulting in lower yields.

Green bean yields were about half of Georgia average yields in the 2nd year and were comparable to conventional production in the 3rd year; however, the first year's yields were a complete loss (Tables 5 and 6 ). In the first year, the variety used was
Yellow Wax, which did poorly and was eventually abandoned. In subsequent years, growers recommended green bean variety Provider, which was used in years 2 and 3 .

The potato variety used in this study was Yukon Gold, a yellowfleshed variety. Yields improved from one year to the next, but never reached the level of reported farm gate yields. The best yields were in the 3 rd year when yields were $85 \%$ of average Georgia yields.

Southernpea were included in rotation A because they offered the benefits of a summer legume and the potential as a fresh market vegetable crop. 'Pink Eye Purple Hull', is a popular southernpea variety that is widely available as a mature-green crop at local outlets. Unfortunately, there were no yields to report in years 1 or 3 , but the year 2 yields were comparable to conventional production. Part of the difficulty with yields in this crop was the short time period between when onion were harvested and the following strawberry crop needed to be planted in year 2 , precluding any southernpea harvest (Table 5).

In year 1, broccoli was grown on plastic mulch to minimize weed problems. In year 2, the crop was grown on bare ground since the winter weed pressure was minimal. Yields improved over the course of the study with the third broccoli crop equivalent to the reported average farm gate yields (Table 6 ). The poor yields the first year may have been due to higher soil temperatures with the black plastic that may have affected yield.

Lettuce production overall was successful in all 3 years of the study with yields better than double the average farm gate yields for Georgia. There is not much conventional lettuce production in Georgia; however, it is a popular crop among organic growers. In the first year, the lettuce was grown on plastic mulch behind broccoli. This practice was abandoned in subsequent years because winter weed pressure was lower than expected and the plastic mulch ended up with too many holes (punched for the broccoli and then for the lettuce). The lettuce variety used was Winter Density, which was pelleted with a clay coating. The pelleting made the seed easier to handle for transplant production. Although the lettuce yields were dramatically higher than Georgia production, they were more in line with national averages for lettuce production, which ranged from 22,403 to $25,204 \mathrm{lb} /$ acre from 2000 to 2009 (USDA, 2011).

Carrot yields were disappointing overall. They are a difficult crop to grow organically because they have small seed, are direct seeded, and are slow growing. Weed control is particularly difficult because of the close spacing and slow growth. Weeds must be controlled very close to the plants particularly during early growth, which is very time consuming and expensive. Yields were less than half the average farm gate values for Georgia. Carrot yields may have also been adversely affected by the previous egyptian wheat/iron clay pea cover crop. Egyptian wheat is in 
the sorghum family and is a locally produced seed. The cover crop was chosen because it has good weed suppression properties and both iron clay pea and sorghum may also help reduce nematode pressure, which would be important before a root crop like carrot. However, the egyptian wheat consistently dominated the cover crop mixture and decomposed slowly. These could have created two negative effects on carrot. First, the sorghum family can have allelopathic properties, which may have affected seed germination and crop growth (Summers et al., 2009). Second, our modeling of $\mathrm{N}$ release in the year 3 indicated there was potential $\mathrm{N}$ immobilization following the egyptian wheat/iron clay pea incorporation (average cover crop $\mathrm{N}=5.3$ $\mathrm{lb} /$ acre, Plot $306=-1.8 \mathrm{lb} /$ acre) . The book value cover crop credit used was $50 \mathrm{~kg} \cdot \mathrm{ha}^{-1}$ and assumed better performance from the iron clay pea in the mixture; consequently, we may have had too little available $\mathrm{N}$ for good carrot production (Table 3 ).

Yield results were mixed in this study. Onion definitely did well in all years consistently producing good yields. This was generally true for lettuce. Although broccoli did not do very well the first year, we believe it, along with potato would be good choices for organic production. Strawberry was inconsistent with good yields in the first year, but subsequent years were disappointing. Bean, southernpea, and carrot, based on this study, did not perform well in these rotations. Economic analyses of the rotation indicate both rotations are potentially profitable. The economic analyses of this study mirrors, for the most part, the yield evaluations presented here (E.G. Fonsah, unpublished data).

\section{Summary and conclusions}

This research indicates that midscale certified organic production can obtain reasonable yields with rotations of organic cool-season vegetables using cover crops in the southeastern United States. The study has shown the potential for several crops including onion, lettuce, broccoli, and potato to be profitable. The study was less successful with several crops including strawberry, carrot, bean, and southernpea. By the end of the study, three (onion, broccoli, and lettuce) of the seven cash crops grown had yields comparable or greater than conventional vegetable yields. This is encouraging because certified organic production often reports reduced yields compared with conventional production. It should be emphasized that this work was with small plots in a research setting. There probably are greater efficiencies with increased size that were not realized in this research.

Several crops showed an increasing trend in yield, which may have been due to increasing grower experience, which has been reported elsewhere (Martini et al., 2004). Rotation studies are complex and difficult to manage.

These rotations can be a good choice for midscale organic growers in the southeastern United States. Rotation costs do go down on average as the scale of the operation increases. Cover crops in rotation are important because of their contribution to soil fertility, managing soil diseases, and controlling weeds. In this study, the cover crops appear to maintain soil organic $\mathrm{C}$, but longer term study is needed to confirm these results and to determine if cover crops alone supply adequate organic matter to suppress RKN populations and other soilborne diseases. Cover crops in some cases were very successful at providing the necessary nutrients for the subsequent crop. For example, sunn hemp and soil supplied $75 \%$ of the onion $\mathrm{N}$ requirement with very good results. But in other cases, the cover crop may have been detrimental because of residual allelopathic effects and difficulty incorporating cover crop residue. Allelopathic effects may not be as great with transplanted crops compared with direct seeded crops. Cover crop selection to provide the benefits desired and proper management needs to be carefully considered in developing successful cool-season rotations for certified organic growers.

\section{Literature cited}

Adam, K. 2006. Organic allium production. 13 May 2016. <https://attra.ncat.org/ attra-pub/summaries/summary.php? $\mathrm{pub}=25>$.

Boatright, S.R. and J.C. McKissick. 2010 2009 Georgia Farm gate vegetable report. Univ. Georgia Ctr. Agribusiness Econ. Dev. AR-10-02.

Chandler, C.K. 2006. Resistance of selected strawberry cultivars to anthracnose fruit rot and botrytis fruit rot. Acta Hort. (708):123-126.

Clark, A. 2007. Managing cover crops profitably. 3rd ed. Sustainable Agr. Res. Educ., College Park, MD.

Copes, W.E. and K.L. Stevenson. 2008. A pictorial disease severity key and the relationship between severity and incidence for black root rot of pansy caused by Thielaviopsis basicola. Plant Dis. 92:1394-1399.

Culman, S.W., S.S. Snapp, M.A. Freeman, M.E. Schipanski, J. Beniston, R. Lal, L. Drinkwater, A.J. Franzluebbers, J.D. Glover, A.S. Grandy, J. Lee, J. Six, J.E. Maul, S.B. Mirsky, J.T. Spargo, and M.M. Wander. 2012. Permanganate oxidizable carbon reflects a processed soil fraction that is sensitive to management. Soil Sci. Soc. Amer. J. 76:494-504.

Dhingra, O.D. and J.B. Sinclair. 1985. Basic plant pathology methods. CRC Press, Boca Raton, FL.

Emory University. 2008. Sustainability initiatives. 16 Oct. 2015. <http:// sustainability.emory.edu/page/1008/ sustainable-food>.

Gianello, C. and J.M. Bremner. 1986. Comparison of chemical methods of assessing potentially available organic nitrogen in soil. Soil Sci. Plant Anal. 17:215-236.

Goulding, K., E. Stockdale, and C. Watson. 2008. Plant nutrients in organic farming, p. 73-88. In: H. Kirchmann and L. Bergström (eds.). Organic crop production-Ambitions and limitations. Springer, Uppsala, Sweden.

Idowu, O.J., H.M. Van Es, G.S. Abawi, D.W. Wolfe, R.R. Schindelbeck, B.N. Moebius-Clune, and B.K. Gugino. 2009. Use of an integrative soil health test for evaluation of soil management impacts. Renew. Agr. Food Syst. 24:214-224.

Kissel, D.E. and L. Sonon (eds.). 2008. Soil test handbook for Georgia. Univ. Georgia Spec. Bul. 62.

Koike, S.T., M. Gaskell, C. Fouche, R. Smith, and J. Mitchell. 2000. Plant disease management for organic crops. Univ. California Agr. Natural Resources Publ. 7252.

Martini, E.A., J.S. Buyer, D.C. Bryant, T.K. Hartz, and R.F. Denison. 2004. Yield increases during the organic transition: Improving soil quality or increasing experience? Field Crops Res. 86:255-266.

Perkins, H.F. 1987. Characterization data for selected Georgia soils. Univ. Georgia Agr. Expt. Sta. Spec. Publ. 47.

Sarrantonio, M. 1992. Opportunities and challenges for the inclusion of soil-improving 
crops in vegetable production systems. HortScience 27:754-758.

Sarrantonio, M. 2007. Building soil fertility and tilth with cover crops, p. 16-24. In: A. Clark (ed.). Managing cover crops profitably. 3rd ed. Sustainable Agr. Res. Educ., College Park, MD.

Schaad, N.W., J.B. Jones, and W. Chun. 2001. Laboratory guide for identification of plant pathogenic bacteria. 3rd ed. APS Press, St. Paul, MN.

Schomberg, H.H., N.L. Martini, J.C. Diaz-Perez, S.C. Phatak, K.S. Balkcom, and H.L. Bhardwaj. 2007. Potential for using sunn hemp as a source of biomass and nitrogen for the piedmont and coastal plain regions of the southeastern USA. Agron. J. 99:1448-1457.

Sharifi, M., B.J. Zebarth, D.L. Barton, C.A. Grant, and J.M. Cooper. 2007. Evaluation of some indices of potentially mineralizable nitrogen in soil. Soil Sci. Soc. Amer. J. 71:1233-1239.

Smith, V.L., C.L. Campbell, S.F. Jenkins, and D.M. Benson. 1988. Effects of host density and number of disease loci on epidemics of southern blight of processing carrot. Phytopathology 78:595-600.
Stapleton, J.J., C.G. Summers, J.P. Mitchell, and T.S. Prather. 2010. Deleterious activity of cultivated grasses (Poaceae) and residues on soilborne fungal, nematode and weed pests. Phytoparasitica 38:61-69.

Stevenson, W.R., R. Loria, G.D. Franc, and D.P. Weingartner. 2001. Compendium of potato diseases. 2nd ed. APS Press, St. Paul, MN.

Summers, C.G., J.P. Mitchell, T.S. Prather, and J.J. Stapleton. 2009. Sudex cover crops can kill and stunt subsequent tomato, lettuce and broccoli transplants through allelopathy. Calif. Agr. 63:35-40.

Thomas, G. 1996. Soil pH and acidity, p. 475-490. In: D.L. Sparks, A.L. Page, P.A. Helmke, R.H. Loeppert, P.N. Soltanpour, M.A. Tabstabai, C.T. Johnston, and M.E. Sumner (eds.). Methods of soil analysis. Part 3-chemical methods. Soil Sci. Soc. Amer., Madison, WI.

University of Georgia. 1991. Georgia automated environmental monitoring network. 16 Oct. 2015. <http://www. georgiaweather.net/>.

University of Georgia. 2011. Agricutlural and environmental services laboratories. 13 July 2016. <http://aesl.ces.uga.edu/>.

University of Georgia Plant Nematology Laboratory. 2004. A quick guide to sampling for nematodes. 16 Oct. 2015.
<http://www.ciids.org/nars/NemaGuide. pdf>.

U.S. Department of Agriculture (USDA) 2011. U.S. lettuce statistics. 27 Aug. 2015. <http://usda.mannlib.cornell. edu/MannUsda/viewDocumentInfo. do? documentID $=1576>$.

U.S. Department of Agriculture (USDA). 2012. U.S. strawberry harvested acreage, yield per acre, and production, 13 states, 1970-2012. 20 Aug. 2015. <http://usda.mannlib.cornell.edu/ MannUsda/viewDocumentInfo.do? documentID $=1381>$.

Wang, Q., W. Klassen, Z.A. Handoo, A.A.A. Baki, H.H. Bryan, and Y. Li. 2002. Influence of summer cover crops on soil nematodes in a tomato field. Proc. Soil Crop Sci. Soc. Fla. 62:86-91.

Wang, Q.R., Y.C. Li, W. Klassen, and Z. Handoo. 2007. Influence of cover crops and soil amendments on okra (Abelmoschus esculentus L.) production and soil nematodes. Renew. Agr. Food Syst. 22:41-53.

Wang, G., M. Ngouajio, and D.D. Warncke. 2008. Nutrient cycling, weed suppression, and onion yield following brassica and sorghum sudangrass cover crops. HortTechnology 18:68-74.

Weil, R.R., K.R. Islam, M.A. Stine, J.B. Gruver, and S.E. Samson-Liebig. 2003. Estimating active carbon for soil quality assessment: A simplified method of laboratory and field use. Amer. J. Altern. Agr. 18:3-17. 